\title{
Transformational Leadership in Nonprofit Organization
}

\author{
Ayuning Budiati \\ University of Sultan Ageng Tirtayasa \\ Banten, Indonesia \\ ayoekomara@gmail.com
}

\author{
Diani Indah \\ University of Langlangbuana \\ Bandung, Indonesia
}

\author{
Idi Jahidi \\ Academy Secretary and Management of Ariyanti \\ Bandung, Indonesia
}

\begin{abstract}
To achieve its objectives, the success of the local government as a nonprofit organization, is determined by the success of the leader. In the case of City of Cimahi, leader success in achieving its objectives, reflected in the type of transformational leadership that is able to influence and mobilize subordinates through idealized influence, inspirational motivation, intellectual stimulation, and individualized consideration in achieving the objectives of the organization.

Keywords- Leader, Transformational Leadership, Nonprofit organizations
\end{abstract}

\section{INTRODUCTION}

As a nonprofit institution in creating a broad regional autonomy, real, and responsible, local government has a position at the forefront in providing public services and welfare improvement. Consequently, local governments in the form of district / city governments need to reform and restructuring of the various components in the system of governance based on the principles of local autonomy.

In order to carry out the reform and restructuring, efforts should be made local government is preparing apparatus Regional Working Units (on education) who can work professionally, and is able to provide public services (public service) to the public in an optimal, in the sense of giving the ease, speed in process, effective and efficient, and accountable. Preparation whole on education is based on the basic rules and ordinances or policies that have been set, so that the local government was able to promote, improve, and empower all minimum standards on education in order to design a public service. Minimum standards on education's ability to provide public services is absolutely necessary in order to achieve the level of satisfaction of public services which in turn will help the realization of the future welfare of the people.

Cimahi development planning can not be separated from human development. In the Medium Term Development Plan Government Cimahi 2007-2012 period, set three criteria for quality human, namely: (1) long and healthy life, (2) intelligent, creative, skilled, educated, and devoted to God Almighty, and (3) independent and have access to a decent life. Based on the above criteria, the achievement of human development fully set forth in the strategic plan Cimahi, the government established six priorities, namely: (1) Increasing economic and employment facilities, (2) Improving the quality of education and health, (3) Increased structuring and law enforcement (4) Improvement of infrastructure; (5) Control of development that environmentally friendly, and (6) Increased partnerships with the corporate world.

Many factors that influence the achievement of the vision, mission, and goals that have been translated into six priorities of the development. One of these factors is determined by the Regional Head Cimahi leadership capable of mobilizing and directing all resources in achieving the organization's vision, mission, and goals.

Local leadership can build a shared commitment between leaders with subordinates. Shared commitment and allows easy collaboration, as well as lightening the workload, so that the vision, mission, and goals can be achieved with the best. Local leadership can also set an example as a leader figure who has the capacity and capability, so it can grow and develop the capacity and ability of subordinates in achieving the vision, mission, and goals. Furthermore, local leadership can motivate, give confidence and authority in decisionmaking through the delegation of authority. This moves and directs subordinates in completing work tasks with high spirit, inspiring, enthusiastic and optimistic, innovative and creative, and create independence.

Based on preliminary research through observation and documentation studies the researchers did, that in carrying out its leadership is not optimal. Moving the head in the area and have not been able to embed and direct the motivation, skills, capabilities, empowerment, confidence, independence, 
creative, innovative, and inspired partly subordinates in achieving the vision, mission, and goals. The head region is not yet fully able to transform the vision of leadership (transformation of the visionary) to get together all the resources to move forward in achieving the organization's vision, mission, and goals Cimahi Government.

\section{RESEARCH METHOD}

This study used a qualitative approach that emphasizes certain research procedures to generate qualitative data, so as to obtain a deep understanding of the problems that were examined (Cresswell, 2007: 37). In this case the researchers wanted to gain a deep understanding of leadership Regional Head Cimahi, so the emphasis on the process, which is explained in a comprehensive leadership Regional Head Cimahi. In accordance with the criteria of a qualitative approach, researchers can examine the issues of leadership Regional Head Cimahi naturally, it is even possible to develop (describe) in detail about the problems studied. In addition to focusing on the process, researchers also seek to understand the symptoms that can reveal the process and find the meaning of leadership Regional Head Cimahi.

The instrument in this study is the researchers themselves, that in qualitative research, the researcher is also a research instrument. In this context, the researcher must be critical, sensitive, and integrate with the object of research. The technique used is the observation that comes with in-depth interviews with key persons, and the making of the record of the events encountered in the field.

Supporting instruments, researchers used a tape recorder, a camera, and a notebook that serves as a tool in the process of data collection. Further analysis of the data in this study is based on the emic perspective and ethics, in order to produce a picture of the deep (thick description) and find meaning.

In this study, the determination of the informant made to people who know and understand about leadership Regional Head Cimahi, namely apparatus Regional Working Units (on education) Cimahi Government, include: 1) Secretariat area; 2) Head Office in Cimahi environment; 3 ) head Office and Board in Cimahi, and 4) Some Cimahi Government Employees who know and understand the local leadership.

Data collection techniques are used as a tool to obtain the necessary data in this study. In this study using data collection techniques include: observation, interviews, and literature/documentation.

The data collected and analyzed through the following activities:

a. Processing unit, data processing begins by examining all the data available from various sources, both the observations, and interviews. Then make a summary of the field notes, which consists of: a record of observations, notes theory, and methodological notes.

b. Categorization, determining the categories on the basis of the mind, intuition, opinion or specific criteria to the data obtained and then put the data in the respective category.

c. Testing the data, performed to measure the validity of the data by triangulation techniques: check, recheck, and crosscheck the data obtained. Triangulation is a technique that utilizes measurement data validity something else out that data for the purpose of checking or comparison data.

d. Interpretation of data, performed using predefined categories. The data have been collected and tested associated with predefined categories. Furthermore, it can be interpreted by plugging an existing concept or theory.

\section{FINDINGS AND DISCUSSION}

Transformational Leadership Regional Head Cimahi, as stated previously determined by the efforts of regional heads in influencing subordinates and moving through: the influence of the ideal (idealized influence), inspirational motivation (inspirational motivation), intellectual stimulation (intellectual stimulation), and individualized consideration (individualized consideration) in achieving the goal.

\section{Ideal influence}

Transformational Leadership Regional Head Cimahi in an effort to influence and mobilize subordinates/employees in achieving organizational goals is done through the influence of the ideal. This category includes subcategories: 1) provide an example of regional head/good example; 2) has the capability of regional heads; 3) regional head has determination; 4) regional heads have perseverance; 5) conduct regional head consistency; 6) regional head bold take risks, and 7) regional head has the confidence of subordinates.

Category ideal influence in transformational leadership Regional Head Cimahi seven subcategories that include the aforementioned as regional head efforts to influence and mobilize subordinates/employees to respect and admire him, so that instill and foster trust subordinate to him. Therefore, the regional heads should give examples/good example, can demonstrate high integrity as mentioned in sub-subcategories above to subordinates/employees. This is as stated by Bass and Riggio (2006: 6) that:

Transformational leaders behave in ways that allow them to serve as role models for their followers. The leaders are admired, respected, and trusted. Followers identify with the leaders and want to emulate them; leaders are endowed by their followers as having extraordinary capabilities, persistence, and determination.

Regional Head Cimahi aware that any belief can foster commitment (responsibility) subordinates/employees, so that the leader can move and direct subordinates/ employees 
together in achieving the vision, mission, and goals of the organization that has been set. This is in line with the Regional Head Cimahi statement, that:

As I grip the leader is the science of administration, that is the main organization leadership and management. Therefore, I run this position with melead (lead) and manage a variety of positions before towards achieving organizational goals is the achievement of public welfare Cimahi. I tried to formulate any positions of trust had to manage as well as possible in order to mancapai organizational goals. (Interview with the Head of Regional Cimahi on Tuesday, July 17, 2012).

Regional Head Cimahi have confidence that the trust subordinates/employees can be obtained through integrity and dedication, therefore as heads of local government to manage and lead by involving subordinates/employees at all levels with the best in achieving the goal. According to Bass and Riggio (2006: 43), transformational leaders gain followers confidence by maintaining integrity and dedication, to be fair, and show good behavior to his.

Below is described transformational leadership subcategories Regional Head Cimahi in influence and mobilize subordinates/employees through the influence of the ideal categories in achieving organizational goals.

Head of regional efforts Cimahi in influencing and moving the subordinates/ employees through the influence of the ideal categories including subcategories such as awarding exemplary/good example. This modeling starts from ourselves both as individuals and as head of the region. As personal and local leaders are fully aware to have the knowledge, education, and extensive knowledge in governance. Therefore, the head of the region continues to increase the knowledge and insight, and even increase their formal education.

Regional Head Cimahi also in giving a good example to subordinates/employees in carrying out their duties and responsibilities always come on time, be nice and neatly dressed, polite, and in accordance with the rules, to provide good service to the community and subordinates/employees, responsible and disciplined.

With the knowledge, insight, and provide an adequate education provision/references to him in carrying out their duties and responsibilities. It is expected to be replicated or imitated well by subordinates/employees, so that every subordinate/employee has stock/reference adequate in performing the duties and responsibilities of each. According to Bass and Riggio (2006: 130-133) that a leader who has a good personal (charismatic), successful, optimistic and will give inspiration and impression to his followers, so that they will follow the example of his superior leadership. With the example of a good leader and subordinates/employees would follow suit indicates confidence in subordinates/employees to the leader and with the confidence slowly growing commitment of subordinates/employees.
Efforts Regional Head Cimahi next in influence and mobilize subordinates/employees through a subcategory of the category of the ideal effect of regional heads have the capability and capacity in the regional administration, ranging from planning and program formulation, implementation, and reporting and evaluation. This is supported by formal and nonformal education, work experience as a bureaucrat since become a civil servant and became government officials in several cities. The whole experience was very supportive in its influence and mobilize subordinates/employees in carrying out their duties and responsibilities. Capability and capacity of the Regional Head Cimahi shown in the regional administration, for example: planning, development, and human resource development, the preparation of the vision, mission, goals, and programs of government work and design achievement strategies, dissemination and implementation of the vision, mission, goals, and programs of work government, and to report and evaluate.

Then the head of regional efforts Cimahi in influencing and moving subordinates/employees through a subcategory of the category of the ideal effect has a strong determination in exercising leadership. The strong determination shown by influence and mobilize subordinates/employees Cimahi carry out implementation of the Government as an autonomous region of the division with the best, earnestly improve human resource capacity and capability in order to have the readiness as government employees, to achieve organizational goals through planning vision, mission, and achievement goals and strategies, implementing various development programs based on the vision, mission, objectives, and strategies that have been set, and perform a variety of changes in implementing development programs that are innovative and creative.

Further efforts Cimahi Head area and move in influencing subordinates/employees through a subcategory of the category of the ideal effect of regional heads have a strong determination. The head is joined to the area and were able to tie subordinates/employees of the institution in the form of a strong determination to carry out their duties and responsibilities. The bonds in an effort to build trust and commitment to both the leader and the organization. As noted by Perry ( 2010: 7 ), that :

Leaders owe the organization a new reference point for what caring, purposeful, committed people can be in the institutional setting. Notice i did not say what people can do what we can do is merely a consequence of what we can be. Corporations, like the people who compose them, are always in a state of becoming. Covenants bind people together and enable them to meet their corporate needs by meeting the needs of one another. Wemust do this in a way that is consonant with the world around us.

Efforts Regional Head Cimahi also in influencing and moving subordinates/employees through a subcategory of the category of the ideal effect of regional heads have 
perseverance. Head region as a leader have perseverance in carrying out its functions and duties, the regional head also moves and directs subordinates/employees to have perseverance in carrying out their duties and responsibilities.

Subsequent attempts Regional Head Cimahi in influencing and moving subordinates/employees through a subcategory of the category of the ideal effect of regional heads have consistency in carrying out its functions and duties. The regional head also moves and directs subordinates/employees to be consistent in carrying out their duties and responsibilities as officers of the regional administration are clean and responsible, and productive performance, integrity, anti- corruption, collusion, and nepotism, consistent in training and capacity building and human resources capabilities, consistent in the planning and design strategies to achieve the vision, mission, and goals of the organization, consistent in the implementation of various development programs, such as: health, data and information systems, public services, population, employment, staffing, etc., are consistent in changes through innovative programs and creative, and consistent in the evaluation and accountability of development programs are planned and implemented.

Later efforts Regional Head Cimahi in influencing and moving the subordinate/employee through a subcategory of the category of the ideal influence regional head preparedness and risk-taking in exercising leadership. The regional head capable of moving and directing subordinates/employees to have the readiness and take risks in carrying out their duties and responsibilities. Readiness and courage to take risks is shown in the form of signing statements and integrity fact anti-corruption, collusion, and nepotism, and legal literacy in carrying out the duties and responsibilities as officers/regional administrator.

Regional Head Cimahi in influencing and moving subordinates/employees through a subcategory of the category of the ideal effect of regional heads to gain the trust of subordinates/employees. Head region showed subordinates/employees in the form of sample/example of good, has the capacity and capability, unwavering in his commitment, perseverance, consistent, and well prepared and willing to take risks both in performing its duties and responsibilities as officers/regional administrator, fostering and develop the capacity and capability of subordinates/employees, plan and design strategies to achieve the vision, mission, and goals of the organization, and implementing development programs in various fields.

Regional Head Cimahi yet fully gain the trust of subordinates/employees, mobilize, and direct it to make changes with innovative programs and creative, as well as to evaluate and account in the planning and implementation of the program. This is in line with the Regional Head Cimahi submitted that :
BITC should have 2 years ago, just on the way a lot of the opinions, including the Parliament can address different about it. Finally we try to run this program in stages up to the entire community aware of the importance of IT. The next program of social engineering, for example in a culture of healthy living. The government is targeting Cimahi community can cultivate a healthy lifestyle within a period of 5 years, which is supposed to be 25 years. 2007 number of dengue fever has come down, it turns on now there are still cases semam beradarahi. Therefore, it takes time to cultivate a culture of healthy living, and supported by an increase in social status, including educational status (Interview with the Head of Regional Cimahi on Tuesday, July 17, 2012).

\section{Motivation Inspiration}

Transformational Leadership Regional Head Cimahi in an attempt to influence and mobilize subordinates/employees in achieving organizational goals is done through motivational inspirational categories. This category includes subsubcategories: 1) providing motivation to subordinates/employees; 2) have enthusiasm; 3) optimism; 4) provide inspiration; 5) engage subordinates/employees; 6) foster team spirit, and 7) have committed to the achievement of destination.

Category inspirational motivation in transformational leadership Regional Head Cimahi seven subcategories that include the aforementioned as regional head efforts to influence and mobilize subordinates/employees motivated and inspired in carrying out their duties and responsibilities. Motivation and inspiration are given to foster regional heads of enthusiasm, optimism, and team spirit to jointly involved in achieving the vision, mission, and goals of the organization. Ultimately the responsibility of subordinates/employees continues to grow and maintained. Bass and Riggio (2006:6) explains that:

Transformational leaders behave in ways that motivete and inspire those around them by providing meaning and challenge to their followers work. Team spirit is aroused. Enthusiasm and optimism are displayed. Leaders get followers involved in envisioning attractive future states; they create Clearly communicated expectations that followers want to meet and also demonstrate commitment to goals and the shared vision.

Transformational Leadership Regional Head Cimahi by influencing and moving subordinates/employees through inspirational motivation category serves to nurture and maintain its commitment to achieving organizational goals . Head area realize that the attitude and confidence of subordinates/employees to have its leadership, this means that the seeds of commitment (responsibility) subordinates/employees have been there, the next attempt is to influence and mobilize regional chief subordinates/employees to develop and maintain and increase 
commitment the . These efforts such as: motivation, enthusiasm, optimism, inspire, involve subordinates/ employees, foster team spirit, and a positive impact is a commitment (responsibility) in achieving the vision, mission, and goals Cimahi Government. It is as expressed by the Regional Head Cimahi, that:

For me success in implementing development programs in Cimahi is an expression of satisfaction from the public on a variety of programs that are run. This can be realized if there has been a paradigm shift subordinates/ employees in the work, initially to be a change in attitude, therefore I did not hesitate to give praise (reward) for those who excel and deliver punishment/reprimand for discipline and there is a change in attitude. I'm not worried this could cause problems, which is essential before there is an example/role model. The principle that I apply for local office, in front gives an example/good example, in the midst of working together, and from behind the push to obtain better results (Interview with the Head of Regional Cimahi on Tuesday, July 17, 2012).

The regional head of the statement in line with the opinion of Bass and Riggio (2006: 3), that the transformational leader is a leader who is able to stimulate and inspire followers to achieve extraordinary results, the ability to develop and empower them in accordance with their needs.

Below is described as a sub-subcategories Regional Head Cimahi in running transformational leadership with a subordinate affect and move through the categories inspirational motivation in achieving the vision, mission, and goals Cimahi Government.

Regional Head Cimahi influence and mobilize subordinates/employees through a subcategory of the category of inspirational motivation motivation to subordinates/employees. The regional head in motivating done by encouraging and developing subordinates/employees to have the ability and skills, foster and develop quality, and promote it in accordance with the needs of subordinates/employees and organizations, encouraging subordinates/employees to do the planning and design strategies achievement, encourage and directs subordinates in the implementation of development programs in various fields such as: data and information system of local government, population, health, education, employment, community service, etc., and encourage and direct subordinates/employees in carrying out the program evaluation and account-programs that have been planned and implemented.

Regional Head Cimahi influence and mobilize subordinates/employees through a subcategory of the category of inspirational motivation regional heads of enthusiasm. Enthusiasm shown by the regional head to pay attention to in order to subordinates/employees carry out their duties and responsibilities as the regional administration as well as possible, productive, achievement, literacy law, anticorruption, collusion, and nepotism, pay attention to training and development of subordinates/employees, pay attention planning and design strategies in achieving the vision, mission, and goals of the organization, pay attention to the implementation of development programs in various fields, such as: population, data management and information system of local government, health, public services, employment, etc., pay attention to implementation of development programs to make the changes that are innovative and creative, giving attention to evaluate and account for programming are planned and implemented.

Regional Head Cimahi influence and mobilize subordinates/employees through a subcategory of the category of inspirational motivation has regional head of optimism. Leaders and subordinates/employees must have confidence in the achievement of the vision, mission, and goals of the organization with planning and design strategies to achieve predetermined. Efforts in the form of regional heads provide optimism in carrying out the duties and responsibilities as officers/regional officials productive, achievement, literacy law, anti-corruption, collusion and nepotism in achieving the vision, mission, and goals of the organization, has in fostering optimism and improve the quality of human resources, has optimism in planning and designing strategies to achieve the vision, mission, and goals of the organization, has optimism in implementing development programs in various fields, such as: population, data and information systems of local government, health, community services, education, employment, staffing, etc., have the optimism to make changes in the implementation of development programs that are innovative and creative, and have optimism in evaluating and accountable for the implementation of programs that have been planned and implemented.

Regional Head Cimahi influence and mobilize subordinates/employees through a subcategory of the category of inspirational motivation to inspire the local chief subordinates/employees. The regional head of the effort include: providing inspiration to become subordinate/employee as officers/regional officials have transparent attitude, be accountable for its work to the public, high integrity, anti-corruption, collusion, and nepotism, as well as legal literacy, providing inspiration to always improve capacity and capability as qualified human resources, productive, able to optimize the potential of existing resources, in order to inspire subordinates/employees can perform planning and design strategies to achieve the vision, mission, and goals of the organization, providing inspiration in the implementation of development programs in various fields, such as: health, data and information system of regional government, public services, demography, education, employment, staffing, etc., in order to inspire subordinates/employees in the implementation of programs to make changes that are innovative and creative, and provide inspiration that subordinates/employees always evaluate and account for programs that have been planned and implemented. 
Further efforts Regional Head Cimahi is moving and directing subordinates/employees by involving them in carrying out their duties and responsibilities in order to achieve the vision, mission, and goals of the organization. These efforts such as: involving subordinates/employees in coaching and human resource development, involving subordinates/employees in the preparation of planning and design strategies to achieve the vision, mission, and goals of the organization, involving subordinates/employees in the implementation of development programs in various fields, such as: population, data and information system of regional government, health, education, employment, community service, etc., and involving subordinates/employees to evaluate and account for the implementation of development programs that have been planned and implemented.

Regional Head Cimahi influence and mobilize subordinates/employees through a subcategory of the category of inspirational motivation regional heads provide team spirit in carrying out their duties and responsibilities in order to achieve the vision, mission, and goals of the organization. Efforts are made in a way: give the team spirit to subordinates/employees in order to improve the quality of human resources through training and development, provide team spirit in the planning and design strategies to achieve the vision, mission, and goals of the organization, encouraging the team to subordinates/employees in the implementation of the program development programs in various fields, such as: data and information system of regional government, population, health, education, employment, community service, etc., and provide team spirit to subordinates/employees to evaluate and account for programs that have been planned and implemented.

Regional Head Cimahi influence and mobilize subordinates/employees through a subcategory of the category of motivational inspirational local leader has committed in carrying out their duties and responsibilities in order to achieve the vision, mission, and goals of the organization. Efforts are made by way of: moving and directing subordinates/employees to have committed as officers/regional officials qualified, productive, legal literacy, anti-corruption, collusion and nepotism in carrying out their duties and responsibilities in order to achieve the vision, mission, and goals of the organization, is committed to developing the capacity and capability of the apparatus/regional government administration through training and human resource development, committed to carrying out planning and design strategies to achieve the vision, mission, and goals of the organization, is committed to the implementation of development programs in various fields, such as: population, healthcare, data and information system of regional government, education, community service, employment, etc., committed in the implementation of development programs by making changes that are innovative and creative, and committed in carrying out evaluation and accountable programs has been planned and implemented.

In carrying out transformational leadership through inspirational motivation category Regional Head Cimahi not fully influence and mobilize subordinates/employees in the form of motivation, involving subordinates/employees, and provide team spirit to subordinates/employees to make changes in the implementation of development programs be innovative and creative. It is as one of the factors behind the failure and success of an innovative program kretatifnya Cimahi, namely Baros Information Technology and Creative (BITC) is still hampered and fully managed. It is as presented by the Regional Head Cimahi, that:

Cimahi already started to prepare HR in IT and Telematics ranging from early childhood/kindergarten, elementary, junior high, high school in the form of events/activities in the form of competitions IT/Telematics and into working groups. Cimahi government also sends employees S1 and S2 to master the field of IT/Telematics. Cimahi also build relationships/networking of various institutions with the BPPT, and thank God finally managed to become Cimahi Acceleration of Indonesian Economic Corridor Industrial Film and Animation fields in Java. Hopefully it can continue to grow steadily and in times to come.

... BITC should have 2 years ago, just on the way a lot of the opinions, including the Parliament can address different about it. Finally we try to run this program in stages up to the entire community aware of the importance of IT. (Interview with the Head of Regional Cimahi on Tuesday, July 17, 2012).

A similar sentiment was expressed in the Focus Group Discussion (FGD), Head of Community Development, Women's Empowerment and Family Planning Cimahi convey, that:

True move and thought the head area very quickly, employees sometimes hard to keep up. But the head of the creative area, made mediation team that can bridge the gap/gap and speed chase step and thought the head area. For example, in applying Information and Communication Technology (ICT) in Cimahi a gap between the head area with employees, even among employees of class $\mathrm{I}$ and $\mathrm{Mr}$ Bambang with employees beginners in understanding the concept (ICT). Finally the head region to form a team of ICTs to bridge the gap and catch up. (Focus Group Discussion (FGD) with Topic: Regional Principal Leadership in City Government Cimahi Cimahi, Friday, April 27, 2012).

\section{Intellectual stimulation}

Transformational Leadership Regional Head Cimahi in an attempt to influence and mobilize subordinates/employees in achieving organizational goals is done through the category of intellectual stimulation. This category includes subsubcategories: 1) regional head using logic decisions based on intuition; 2) regional head make improvements outdated 
tradition; 3) regional head using new approaches; 4) encourage regional head of public criticism; 5) conduct regional head creativity; 6) regional head of innovation, and 7) the head of the organization confidence regions make improvements.

Categories of intellectual stimulation in transformational leadership Regional Head Cimahi seven subcategories that include the aforementioned as regional head efforts to influence and mobilize subordinates/employees have the innovation and creativity, the way to solve problems in new ways and more creative and able to maintain the trust and enhancing the reputation of the organization. Bass and Riggio (2006: 7) states that:

Transformational leaders stimulate their followers Efforts to be innovative and creative by questioning Assumptions, reframing problems, and approaching old Situations in new ways. Creativity is encouraged. There is no public criticism of individual members mistakes. New ideas and creative problem solutions are solicited from followers, who are included in the process of addressing problems and finding solutions. Followers are encouraged to try new approaches, and their ideas Criticized Because they are not different from the leaders ideas.

Cimahi regional head in an attempt to influence and mobilize subordinates/employees by category of intellectual stimulation as a follow-up to the previous run transformational leadership, after understanding and have confidence that subordinates/employees have had the confidence and commitment to the category itself as a leader through the influence of the ideal and inspiring motivational. This is the time for the Regional Head Cimahi influence and mobilize subordinates/ employees together in achieving the vision, mission, and goals of the organization by using approaches and new strategies, creative, and innovative. With transformational leadership through intellectual stimulation category is expected to keep and maintain the trust of the organization and enhance the good name/image of the Government of Cimahi positive . This is in line with the Regional Head Cimahi statement, that :

What to do this, essentially a reference. The head should have a reference area with the best human resources, understand the input and recruitment patterns, commitment, and their position, so that when we need to something more, innovation programs, we can search required for these changes. Then we also have to follow the rules relating to rank and increase in class with regard to that employee must have and understand the various references and strategic frameworks, so that it can compete. ( Interview with the Regional Head Cimahi on Tuesday, July 17, 2012).

Head area and move in influencing subordinates/employees by category of intellectual stimulation to prepare human resources recruitment and selection pattern rigorous and correct, manage differences and individual needs in accordance with the needs of the organization, provide training and development in order to have a better performance and extraordinary, so encourage subordinates/employees creative and innovate. It is as the opinion of Bass and Riggio (2006 : 127-128) that:

Transformational leadership presents opportunities for improving the organization 's image, recruitment, selection, promotion, management of diversity, teamwork, training, development, and ability to innovate. It also has implications for the organization's strategic planning and the design of its jobs and organizational structure. Policies can be set in place that arrange for a desirable mix of transformational and transactional styles to Appear in the leadership displayed by the individual members of an organization. Such policies can influence the norms, values, and culture of the organization itself. As a consequence, various aspects of the organization, ranging from strategic planning to employee selection, will be affected Favorably.

Then the statement of the Regional Head Cimahi also strengthened with the opinion of Morse and Buss (2008: 61) that:

Transformational leadership exhibited by academic department chairs has the potential to substantively and positively impact the academic departments by positioning them to face challenges and be more adaptive to environmental changes. Positioning academic departments Refers to shaping the departmental culture so that it is reflective of what Cooke and Lafferty (1983) termed "constructive organizational cultural norms." Constructive cultural norms are Characterized by organizational learning that is facilitated by open communication and striking a balance between organizational goals and members' needs.

Below is described the efforts of the Regional Head Cimahi in running with the influence of transformational leadership and subordinates moving through categories of intellectual stimulation in achieving the vision, mission, and goals Cimahi Government.

Regional Head Cimahi influence and mobilize subordinates/employees through a subcategory of the category of intellectual stimulation regional head can carry out the decisions based on intuition logic associated with the tasks and responsibilities in achieving the vision, mission, and objectives of organizations. Efforts done by regional heads: moving and directing subordinates to understand and have the awareness to implement Undang-Undang Nomor 14 Tahun 2008 tentang Keterbukaan Informasi Publik and the statutes and decisions of regional heads Perwal Nomor 4 Tahun 2011 tentang Pejabat Pengelola Informasi dan Dokumentasi (PPID) Cimahi, which became the apparatus/regional officials clean, implement and follow the decisions and statutes in coaching and human resource development, understand and implement the decisions and statutes concerning the planning and strategies to achieve the vision, mission, and goals of the organization, understand and implement the decisions and statutes in the implementation development programs in 
various fields, such as: community service, data and information system of local governance, education, population, employment, and others, and to understand and carry out the decisions and statutes in evaluating and accountable for the implementation of programs that have been planned and implemented.

Regional Head Cimahi influence and mobilize subordinates/employees through a subcategory of the category of intellectual stimulation regional head moves and directs subordinates/employees can fix customs/traditions long with custom/new traditions, such as: subordinates/employees have an attitude and a way of working that is clean, transparent, legal literacy, and anti-corruption, collusion, and nepotism as officers/regional government administration, implementation planning and design strategies to achieve the vision, mission, and goals of the organization, the implementation of development programs in various fields such as: population, health, data and information systems the regional administration, community services, education, employment, and others, the implementation of development programs by making changes that are creative and innovative, evaluation and accountability of programs that have been planned and implemented.

Regional Head Cimahi influence and mobilize subordinates/employees through a subcategory of the category of intellectual stimulation regional head moves and directs subordinates/employees to be able to use strategies or new approaches in carrying out their duties and responsibilities as officers/regional officials legal literacy, clean, anti-corruption, collusion, and nepotism, using a strategy/new approach in coaching and human resource development, using a strategy/new approach in the planning of development programs in order to achieve the vision, mission, and goals of the organization, using strategy/approach in the implementation of programs various fields, such as: population, data and information systems areas of governance, health, education, employment, community service, etc., using the strategy/new approach in the implementation of development programs that are creative and innovative, using strategy/approach new account in evaluating and implementing programs that have been planned and implemented.

Regional Head Cimahi influence and mobilize subordinates/employees through a subcategory of the category of intellectual stimulation and direct regional head move by encouraging subordinates/employees to accept criticism, suggestions, and constructive input in performing their duties and responsibilities as officers/regional officials legal literacy, clean, anti-corruption, collusion, and nepotism, encourage subordinates/employees can accept criticism, suggestions, and input in the coaching and development of human resources, encourage subordinates/employees to accept criticism, suggestions, and input in the planning and design strategy achievement of the vision, mission, and goals of the organization, encouraging subordinates/employees to be able to accept criticism, suggestions, and input in the implementation of development programs in various fields, such as: population, data and information system of regional government, health, employmen, etc. another, encourage subordinates/employees to accept criticism, suggestions, and feedback to evaluate and account for programs that have been planned and implemented.

Regional Head Cimahi influence and mobilize subordinates/employees through a subcategory of the category of intellectual stimulation regional head moves and directs subordinates/employees to have a creative attitude in carrying out their duties and responsibilities to become officers/regional officials clean, transparent, legal literacy, anti-corruption, collusion, and nepotism, has creativity through the development and implementation of human resource development, creativity in planning and designing strategies to achieve the vision, mission, and tujan organization, has creativity in the implementation of programs in areas such as: data and information systems providers local government, public services, health, education, population, employment, and others, have the creativity to make changes in the implementation of development programs, and carry out the creativity in evaluating and accountable for the implementation of the proram-programs that have been planned and implemented.

Regional Head Cimahi influence and mobilize subordinates/employees through a subcategory of the category of intellectual stimulation regional head moves and directs subordinates/employees to perform by way of fostering innovation and human resource development, innovation in the planning and design strategies to achieve the vision, mission, and goals of the organization, make innovations in the implementation of development programs in various fields, such as: data and information system of regional government, public service, education, population, employment, and others, to make changes in development programs that are innovative, do account in evaluating the innovation and implementation of programs that have been planned and implemented.

Regional Head Cimahi influence and mobilize subordinates/employees through a subcategory of the category of intellectual stimulation regional head moves and directs subordinates/employees to maintain the trust and enhance the positive image of the organization through the implementation of the duties and responsibilities as officers/regional officials performing, productive, achievement, clean, legal literacy, anti-corruption, collusion, and nepotism, maintain trust and enhance the positive image of the organization through coaching and people development, maintaining trust and increase the positive image of the organization through the planning and design strategies to achieve the vision, mission, and goals of the organization, maintaining confidence and enhance the positive image of the organization through the 
implementation of development programs in various fields, such as: population, data and information systems areas of governance, health, community services, education, employment, and others, maintain trust and enhance the positive image of the organization to perform changes in development programs that are creative and innovative, and maintain the trust and enhance the positive image of the organization through the implementation and evaluation of programs to account for planned and implemented.

\section{Individual consideration}

Transformational Leadership Regional Head Cimahi in an attempt to influence and mobilize subordinates/employees in achieving organizational goals is done through consideration of individual categories. This category includes subsubcategories: 1) identify the capabilities and needs of subordinates/employees; 2) understand and accept the existence of individual differences; 3) provide training and improve the ability and skill; 4) empower subordinates/employees; 5) provides the opportunity for subordinates/employees to learn; 6) delegate certain authority to subordinates/employees; 7) two-way communication with subordinates/employees; 8) listen effectively a variety of input and suggestions from subordinates/employees, and 9) carrying out the functions of management is driving around in unit.

Categories individual consideration in transformational leadership Regional Head Cimahi nine subcategories that include the aforementioned as regional head efforts to influence and mobilize subordinates/employees to have more potential, so as to produce exceptional performance. Bass and Riggio (2006: 7) states that:

Transformational leaders pay special attention to each individual follower's needs for achievement and growth by acting as a coach or mentor. Followers and colleagues are developed to successively higher levels of potential. Individualized consideration is practiced when new learning opportunities are created along with a supportive climate. Individual differences in terms of needs and desires are recognized companies. The leader's behavior demonstrates acceptance of individual differences (eg, some employees receive more encouragement, some more autonomy, others fi rmer standards, and still others more task structure). A twoway exchange in communication is encouraged, and "management by walking around" workspaces is practiced. Interactions with followers are personalized.

Head transformational leadership Cimahi area through consideration of individual categories in an effort to mobilize and direct subordinates/employees to have better performance and outstanding. Previous subordinates/employees have had the confidence and commitment, motivation and inspiration to creativity and innovation, further efforts Regional Head Cimahi is moving and directing subordinates/employees together in achieving the vision, mission, and goals of the organization by identifying the capabilities, skills, desires and needs of the individual differences, training, providing opportunities to learn, optimally empower, delegate certain tasks or authority, and conduct management around. With transformational leadership through the individual consideration category, is expected to improve the performance and productivity of subordinates/employees more and outstanding, committed, motivated, creative and innovative in achieving the vision, mission, and goals Cimahi Government. This is in line with the Regional Head Cimahi statement, that:

I implement them flexibly sometimes formal and sometimes informal. At the beginning I did formally, due to the same perception and motion with colleagues, commitment, and understanding of the strategies for achieving the programs. The next task in the implementation of the Secretary there. As the head of the region, need to know whether in the field went well as expected. In this case crosscheck to do, I wandered up to the entrance, moving together they discover and resolve problems. The things that are done to maintain the condition of non-formal and consistency and similarity of reference in the implementation of programs .

... I agree that subordinates/employees have the ability/skill and smart will greatly assist and facilitate the work. But instead of subordinates/employees " minterin ", because employees who have this attitude will do the violations end up stuck in Collusion, Corruption and Nepotism $(\mathrm{KKN})$. I as a leader should not be afraid to be shifted, different flying hours, it subordinates/employees who advance will greatly assist the leadership in implementing programs and develop it. In the process I give the trust and delegate programs to subordinates/employees, on the eve of execution as a leader I try to evaluate whether prior to execution of the program is qualified or not. When programs are delegated yet qualified, then I try to pay attention to the various desires of subordinates/employees and restructure the program, so it can be done well. Here is my lot down the mountain in order Sharring, so that peers with a reference and referral implement various references. (interview with the Regional Head Cimahi on Tuesday, July 17, 2012).

Transformational Leadership Regional Head Cimahi through consideration of individual categories in an effort to optimize the potential (commitment, motivation, and inspiration) followers by moving and directing subordinates/employees by empowering (train, guide, and provide an opportunity), so challenged to perform more productive and enhancing leadership capacity. As noted by Bass and Riggio (2006 : 4), that:

Transformational leadership is in some ways an expansion of transactional leadership. Transactional leadership emphasizes the transaction or exchange that takes place among leaders, colleagues, and followers. This exchange is based on the leader discussing with others what is required and Specifying the conditions and rewards these others will receive if they fulfill those requirements. Transformational leadership, however, raises leadership to the next level. 
Transformational leadership involves inspiring followers to commit to a shared vision and goals for an organization or unit, challenging them to be innovative problem solvers, and developing followers leadership capacity via coaching, mentoring, and provision of both challenge and support.

Below is described the efforts of the Regional Head Cimahi in running with the influence of transformational leadership and subordinates moving through consideration of individual categories in achieving the vision, mission, and goals Cimahi Government.

Regional Head Cimahi influence and mobilize subordinates/employees through individualized consideration a subcategory of the category of the head region to identify the capabilities and skills in a way: knowing and understanding the capabilities and capacity of subordinates/employees through training and development of human resources, identify the capability and capacity of subordinates/employees in the implementation development programs in various fields such as: data and information system of regional government, health, population, community service, etc., identify the capability and capacity to evaluate subordinate and accountable programs that have been planned and implemented.

Regional Head Cimahi influence and mobilize subordinates/employees through individualized consideration a subcategory of the category of regional head coach, guiding, and with him on improving capabilities and skills through training programs and human resource development, training, guidance, and assistance in planning and designing strategies to achieve vision, mission, and goals of the organization, providing training, guidance, and assistance in the implementation of programs in various fields, such as: population, data and information system of local governance, health, education, employment, etc., and training, guiding, as well as assisting subordinates/employees to evaluate and account for programs that have been planned and implemented.

Regional Head Cimahi influence and mobilize subordinates/employees through individualized consideration a subcategory of the category of regional heads empower subordinates/employees. Empowerment is done by optimizing the full potential by subordinates/employees. Armed with knowledge and understanding of the regional head of the identification capability and capacity, as well as the differences in the needs and desires of subordinates/employees, head to optimize the implementation of regional programs for the achievement of the vision, mission, and goals of the organization. Empowering regional heads subordinates/employees in coaching and human resource development, empowering subordinates/employees in the planning and design strategies to achieve the vision, mission, and goals of the organization, empowering subordinates/employees in the implementation of programs in various fields, such as: population, data and system information of regional government, health, education, employment, community service, etc., and empowering subordinates to evaluate and account for programs that have been planned and implemented.

Regional Head Cimahi influence and mobilize subordinates/employees through a subcategory of the category of individual consideration of regional heads provide learning opportunities to subordinates in improving capabilities and skills through training programs and human resource development, providing learning opportunities in planning and designing strategies to achieve the vision, mission, and organizational goals, providing learning opportunities in the implementation of development programs in various fields, such as: population, health, data and information system of regional government, education, employment, community service, etc., and provide learning opportunities to evaluate and account for programs that have been planned and implemented.

Regional Head Cimahi influence and mobilize subordinates/employees through individualized consideration a subcategory of the category of regional head delegate certain authority to increase the capabilities and skills of subordinates/employees through training programs and human resource development to delegate certain authority in the planning and design strategies to achieve the vision, mission, goals organization, delegate certain authority in the implementation of development programs in various fields, such as: population, data and information system of regional government, health, education, employment, community service, etc., to delegate authority to evaluate and account for programs planned and implemented.

Regional Head Cimahi influence and mobilize subordinates/employees through individualized consideration a subcategory of the category of regional head two-way communication in a subordinate capacity building and skills through training programs and human resource development, two-way communication in planning and designing strategies to achieve the vision, mission, and objectives of the organization, two-way communication in the implementation of development programs in various fields, such as: population, data and information system of regional government, health, education, employment, community service, etc., and two-way communication in doing evaluation and account for programs that have been planned and implemented.

Regional Head Cimahi influence and mobilize subordinates/employees through individualized consideration a subcategory of the category of the head region of expression in the form of criticism and suggestions that are built to a leader in enhancing the capabilities and skills of subordinates/employees through training programs and human resource development, expression in the form of criticism and 
suggestions that are built to a leader in planning and design strategies to achieve the vision, mission, and goals of the organization, either in the form of expression of criticism and suggestions that are built to a leader in implementing development programs in various fields, such as: population, data and system information of regional government, health, education, community service, employment, etc , either in the form of expression of criticism and suggestions that are built to the leader to evaluate and account for programs that have been planned and implemented.

Regional Head Cimahi influence and mobilize subordinates/employees through individualized consideration a subcategory of the category of the head of the management area did get around to subordinates/employees in improving the capabilities and skills through training programs and human resource development, management did get around to subordinates/employees in planning and designing strategies achievement of the vision, mission, and goals of the organization, management did get around to subordinates/employees in the implementation of programs in various fields, such as: population, health, data and information system of regional government, employment, community service, etc., and do management around to subordinates/employees to evaluate and account for programs that have been planned and implemented.

Thus, transformational leadership Regional Head Cimahi performed with emphasis on the influence and mobilize subordinates/employees in the establishment of commitment (responsibility), namely: through the influence of the ideal categories that serve to embed and grow the seeds of trust and commitment to subordinates/employees; through foster functioning category inspirational motivation and commitment to encourage and stimulate subordinates to perform more than expected; through subordinate categories of intellectual stimulation that is able to search for and find new ways to make changes in the implementation of development programs are more creative and innovative, and through the categories of individual consideration and support functions to support the belief, commitment, motivation, performance, creativity and innovation subordinates/employees to be more effective by giving full attention, provide training, guidance and mentoring, and support. According to Bass and Riggio (2006 : 50-51), that transformational leadership:

In short, transformational leaders Enhance the selfconcepts of followers and Encourage followers personal and collective identification with both the leader 's and the organizations goals and objectives. This is further enhanced by the follower becoming engaged in the challenges of the mission as set forth by the transformational leader, the identification of the followers self with the successful leader and team effort, the exciting experience of unexpected discoveries, and a sense of empowerment by way of association with a successful leader. The resulting performance is beyond what would be motivated by other forms of leadership, such as purely transactional behavior.
Broken down, this theory Suggests several mediators affecting the relationship between transformational leadership and exceptional performance. First, transformational leaders Enhance the self - concept and sense of self -efficacy of followers. Self-efficacy has been shown to consistently Enhance both individual and group performance. Second, identification with the leader, both individually and Collectively, and identification with the group or unit are important. Third, shared or aligned goals and values are key to motivating follower performance. Finally, the transformational leader empowers followers to perform beyond expectations. We consider each of the first three mediators of the transformational leadership-performance relationship Briefly here and focus on the role of empowerment and transformational leadership.

In other words, transformational leadership Regional Head Cimahi done in a way to influence and mobilize subordinates/employees through categories: 1) the influence of the ideal, 2) inspirational motivation, 3) intellectual stimulation, and 4) individualized consideration. The fourth category of transformational leadership Regional Head Cimahi is used for effectiveness in achieving the vision, mission, and goals Cimahi Government.

\section{CONCLUSION}

Based on these results the following conclusions can be drawn, transformational leadership in the nonprofit leaders in an effort to influence and mobilize subordinates/employees through idealized influence, inspirational motivation, intellectual stimulation, and individualized consideration in achieving the goal.

Leaders influence and mobilize subordinates/employees through the idealized influence, such as: provide exemplary, demonstrated ability/capability, showing a strong determination, have perseverance, gain confidence, courage to take risks, and be consistent.

Leaders influence and mobilize subordinates/employees through Inspirational Motivation, such as: motivation, inspiration, commitment, foster team spirit, enthusiasm, optimism, and involving subordinates/employees.

Leaders influence and mobilize subordinates/employees through Intellectual Stimulation, such as: innovation, creativity, formulating strategies and new approaches, receive public input and criticism, implementing decisions based on intuitive logic, correct habits (traditions) which has been usual with new and more creative, and improve and maintain a good reputation and the trust of the organization.

Leaders influence and mobilize subordinates/employees through Individual Confederation, comprising: providing training, carry around management, identify capabilities and needs of subordinates/employees, accept the existence of individual differences, giving the opportunity to learn, delegate authority, empower, and listen effectively. 


\section{REFERENCES}

Bass, B.M. 1981. Stogdil's Handbook of Leadership, A Survey of Theory and Research. Revised and Expanded. New York: Free Press

Bass, B.M. and Riggio Ronald E. 2006. Transformational Leadership. Second Edition. New Jersey: Lawrence Erlbaum Associates, Inc.

Basuki, Johanes. tt. Tantangan Ilmu Administrasi Publik: Paradigma Baru Kepemimpinan Aparatur Negara. Jakarta: STIA LAN.

Burns, J.M. 1978. Leadership. New York: Harper and Row.

Creswell, John, W. 1994. Qualitative Inquiry and Research Design: Choosing Among Five Traditions. London: Sage Publications.

Fairholm, Matthew R. and Fairholm, Gilbert W. 2009. Understanding Leadership Perspectives (Theoretical and Practical Approaches). New York: Springer.

Goethals, George R. and Sorenson, Georgia L.J. 2006. The Quest for A General Theory of Leadership (New Horizon in Leadership Studies). Massachusetts USA: Edward Elgar Publishing, Inc.

Hawkins, Peter. 2011. Leadership Team Coaching: Developing Collective Transformational
Leadership. United States: Kogan Page Limited.

Morse, Ricardo S. and Buss, Terry F. 2008. Innovations in Public Leadership Development., New York: M.E.Sharpe Armonk.

Perry, James L. Perry. 2010. The Jossey-Bass Reader on Nonprofit and Public Leadership. San Francisco: Jossey-Bass AWiley Imprint

Robbins, Stephen P. 2008. Perilaku Organisasi (Buku 2). (Terjemahan). Edisi 12. Jakarta: Salemba Empat.

Yukl, Gary. 2010. Leadership in Organization (Terjemahan). Jakarta: PT. Indeks.

\section{Law:}

Undang-Undang Nomor 9 Tahun 2001 tentang Pembentukan Kota Cimahi.

Undang Undang Nomor Nomor 32 Tahun 2004 tentang Otonomi Daerah.

Peraturan Daerah Nomor 3 Tahun 2008 Tentang Rencana Pembangunan Jangka Menengah Daerah (RPJMD) Kota Cimahi Periode 2007-2012. 